О. П. Венгер, Т. П. Гусєва, Ю. І. Мисула, Л. М. Сас, О. Є. Смашна, В. С. Білоус, О. О. Люта, Я. М. Несторович ДВНЗ “Тернопільський державний медичний університет імені І. Я. Горбачевського мОЗ України”

\title{
МОТИВАЦІЯ ДОСЯГНЕННЯ ЯК ВАЖЛИВИЙ ЧИННИК УСПІШНОГО ПРОФЕСІЙНОГО СТАНОВЛЕННЯ СТУДЕНТІВ-МЕДИКІВ
}

\author{
O. P. Venger, T. P. Husyeva, Yu. I. Mysula, L. M. Sas, O. Ye. Smashna, V. S. Bilous, \\ O. O. Liuta, Ya. M. Nestorovysch \\ I. Horbachevsky Ternopil State Medical University \\ MOTIVATION OF ACHIEVEMENT AS AN IMPORTANT FACTOR \\ OF SUCCESSFUL PROFESSIONAL DEVELOPMENT OF MEDICAL \\ STUDENTS
}

\begin{abstract}
Мета роботи - визначити динаміку мотивації досягнення успіху в студентів 2-го та 4-курсів медичного факультету.
Основна частина. Професійне становлення молодої людини під час навчання у вищому навчальному закладі $є$ важливим етапом у її соціалізації, де провідним видом діяльності стає навчально-професійна. У статті висвітлені етапи професійного становлення студента-медика. Мета дослідження полягала у визначенні динаміки мотивації досягнення успіху в студентів-медиків 2-го та 4-го курсів медичного факультету. В дослідженні брали участь 112 студентів, з яких 56 студентів 2-го курсу та 56 студентів 4-го курсу медичного факультету. Розглянуто особистісні характеристики респондентів за рівнем мотивації досягнення успіху.

Висновки. Отримані результати свідчать про те, що мотивація досягнення успіху в студентів за період навчання має тенденцію до зростання. На здійснення ними навчальної діяльності впливає система внутрішніх мотивів, що забезпечує ефективне оволодіння майбутнім фахом.
\end{abstract}

Ключові слова: мотивація; мотивація досягнення успіху; професійне становлення.

The aim of the work - to determine the dynamics of the motivation to succeed in medical students of the 2nd and 4th courses of the medical faculty.

The main body. The professional formation of a young person during studying at a higher educational institution is an important stage in its socialization, where the leading kind of activity becomes educational-professional. The motivational component plays an important role in the training of a highly skilled specialist. The aim of the study was to determine the dynamics of the motivation to succeed in medical students of the 2nd and 4th courses of the medical faculty. The study included 112 students, 56 of whom were students of the second year and 56 - students of the 4th year of the medical faculty. We consider the personal characteristics of respondents by level of motivation to achieve success.

Conclusions. The received results indicate that the motivation to achieve success in students during the study period tends to increase. Their educational activity is influenced by the system of internal motives, which ensures effective mastery of the future specialty.

Key words: motivation; motivation for success; professional formation.

Вступ. Однією з актуальних проблем сучасної медичної освіти є підвищення якості професійної підготовки майбутніх лікарів, які мають кваліфіковано вирішувати поставлені професійні задачі та бути соціально успішними, прагнуть до подальшого професійного та особистісного розвитку.

На процес будь-якої діяльності впливає мотиваційна складова. Особливо це стосується майбутніх лікарів, адже недостатній рівень мотивації позначається негативно на особистій активності студен-

() О. П. Венгер, Т. П. Гусєва, Ю. І. Мисула та ін. тів-медиків у навчальному процесі та їх успішності у майбутній професійній діяльності.

Серед сучасних психолого-педагогічних досліджень різних аспектів мотиваційної діяльності студентів науковцями розглядаються сучасні можливості підвищення мотивації студентів до навчання (Л. В. Беш, Б. Я. Дмитришин, О. М. Беш, О. І. Яскевич, О. І. Мацюра), мотиви вступу до вищого навчального закладу (С. В. Бобровицька, О. В. Гилюн), умови виникнення у студентів позитивної мотивації до навчально-пізнавальної діяль- 
ності (С. С. Занюк, В. В. Полянська), досягнення як чинник мотивації студентів (Б. С. Коломієць).

Мотивація навчальної діяльності студентів $є$ предметом досліджень вчених: М. Боришевського, М. Дьяченко, Є. Ільїна, Л. Кандибович, Ю. Орлова, Є. Просецького, В. Семиченко.

Важливим різновидом мотивації професійної підготовки студентів-медиків, який пояснює поведінку людини, спрямовану на саморозвиток й самовдосконалення, та значною мірою визначає її спрямованість на успішну професійну діяльність, $є$ мотивація досягнення.

Проблеми мотивації досягнення знайшли висвітлення у працях таких учених, як: Б. Аткінсон, С. Занюк, Т. Гордєєва, М. Кондратьєва, Д. МакКлелланд, Л. Мітіна, А. Орлов, А. Сальков, Х. Хекхаузен.

Однак питання розвитку мотивації досягнення студентів-медиків вивчені недостатньо і залишаються актуальними.

Мета роботи - визначити динаміку мотивації досягнення успіху в студентів 2-го та 4-курсів медичного факультету.

Основна частина. Професійне становлення молодої людини під час навчання у вищому навчальному закладі є важливим етапом у її соціалізації, де провідним видом діяльності стає навчально-професійна. Професійна підготовка у вищих навчальних закладах майбутніх спеціалістів охоплює надбання тієї системи цінностей, світогляду, практичного досвіду, які необхідні для ефективної професійної діяльності.

Становлення студента як фахівця здійснюється у фізичному, психофізіологічному і когнітивному напрямах розвитку особистості. Б. Г. Ананьєв вважав, що цей період найсприятливіший для навчання та професійної підготовки [1].

С. С. Занюк визначає, що будь-яка діяльність людини визначається певними мотивами, оскільки мотиви - це те, заради чого виконується діяльність. Отже, мотивація - це сукупність спонукальних факторів, які визначають активність особистості; до них відносяться мотиви, потреби, стимули, ситуативні фактори, які детермінують поведінку людини [2].

Успішність професійного становлення студента, як зазначає Е. Зеєр, залежить від особистої активності студента, від наявності відповідних мотивів [3]. Ці мотиви визначають різні рівні активності студента в навчально-професійній діяльності: 1) вищий рівень - коли навчально-професійна діяльність приносить радість творчості; 2) виконавчий рівень - коли студент лише є “споживачем культури”, який копіює зразки виконання навчальної діяльності з інших авторитетних осіб.

Мотив досягнення як стійка характеристика особистості уперше був виділений Г. Мюрреєм і розумівся як стійке прагнення зробити щось швидко і добре, досягти певного рівня в будь-якій справі. У процесі подальших досліджень цього мотиву такими ученими, як Д. Мак-Клелланд і Х. Хекхаузен, були виявлені дві незалежні мотиваційні тенденції: прагнення до успіху і прагнення уникнути невдачі. Мотив досягнення в даному випадку показує, наскільки людина прагне до підвищення рівня своїх можливостей [7].

Мотивація до успіху тісно пов'язана із самооцінкою та рівнем домагань особистості. Як вказують дослідники, успіх у діяльності залежить не тільки від здібностей і знань, а й від мотивації, прагнення самостверджуватись, досягати високих результатів. Мотивація визначає потенційні можливості особистості, активність або пасивність суб’єкта в професійній діяльності, визначає професійний розвиток спеціаліста [7].

Мотив досягнення успіху - це прагнення людини досягнути успіхів у діяльності і спілкуванні. Мотив уникнення невдач - відносно стійке прагнення людини уникнути невдач у життєвих ситуаціях, пов’язаних з оцінкою результатів її діяльності іншими людьми. Мотивація досягнення успіху пов’язана також з такою особистісною характеристикою, як локус контролю. Локус контролю це якість, яка характеризує схильність людини приписувати відповідальність за результати своєї діяльності зовнішнім факторам і обставинам (зовнішній локус) або власним зусиллям і здібностям (внутрішній локус). Схильність до зовнішнього локусу контролю властива людям, невпевненим у своїх здібностях, неврівноваженим, несамостійним у прийнятті рішень, часто безвідповідальним. Люди з внутрішнім локусом контролю є послідовними, наполегливими в досягненні мети, впевненими в собі, врівноваженими, незалежними, схильними до самоаналізу і критичної самооцінки [2].

Динаміка професійного становлення студента змінюється впродовж усього періоду навчання [1].

Зокрема, на першому курсі вирішується завдання адаптації до нових умов вузівського навчання. Поведінка студентів характеризується високим рівнем конформізму, відсутністю диференційованого підходу до своїх соціальних ролей. На другому курсі 
студенти отримують загальну підготовку, водночас формуються та розвиваються їхні запити та потреби. Процес адаптації до освітнього середовища, в цілому, завершений. Третій курс - це початок професійної спеціалізації, зміцнення інтересу до наукової роботи, як відображення подальшого розвитку й поглиблення професійних інтересів студентів. На четвертому курсі відбувається безпосереднє знайомство з роботою в клініці. Для поведінки студентів характерним $є$ інтенсивний пошук раціональних шляхів і форм спеціальної підготовки, відбувається переоцінка студентами багатьох професійних, особистісних та життєвих цінностей. П'ятий - шостий курс - це перспектива закінчення вищого навчального закладу формує чіткі практичні настанови на майбутню сферу діяльності.

Нами було проведено дослідження, у якому брали участь 112 студентів, з яких 56 студентів 2-го курсу та 56 студентів 4-го курсу медичного факультету. Основним психодіагностичним інструментарієм дослідження стала методика вивчення мотивації досягнення успіху Т. Елерса, яка містить 41 судження і діагностує 4 рівні мотивації досягнення: низький, середній, високий, дуже високий.

Візуалізація отриманих даних представлена на рисунку 1.

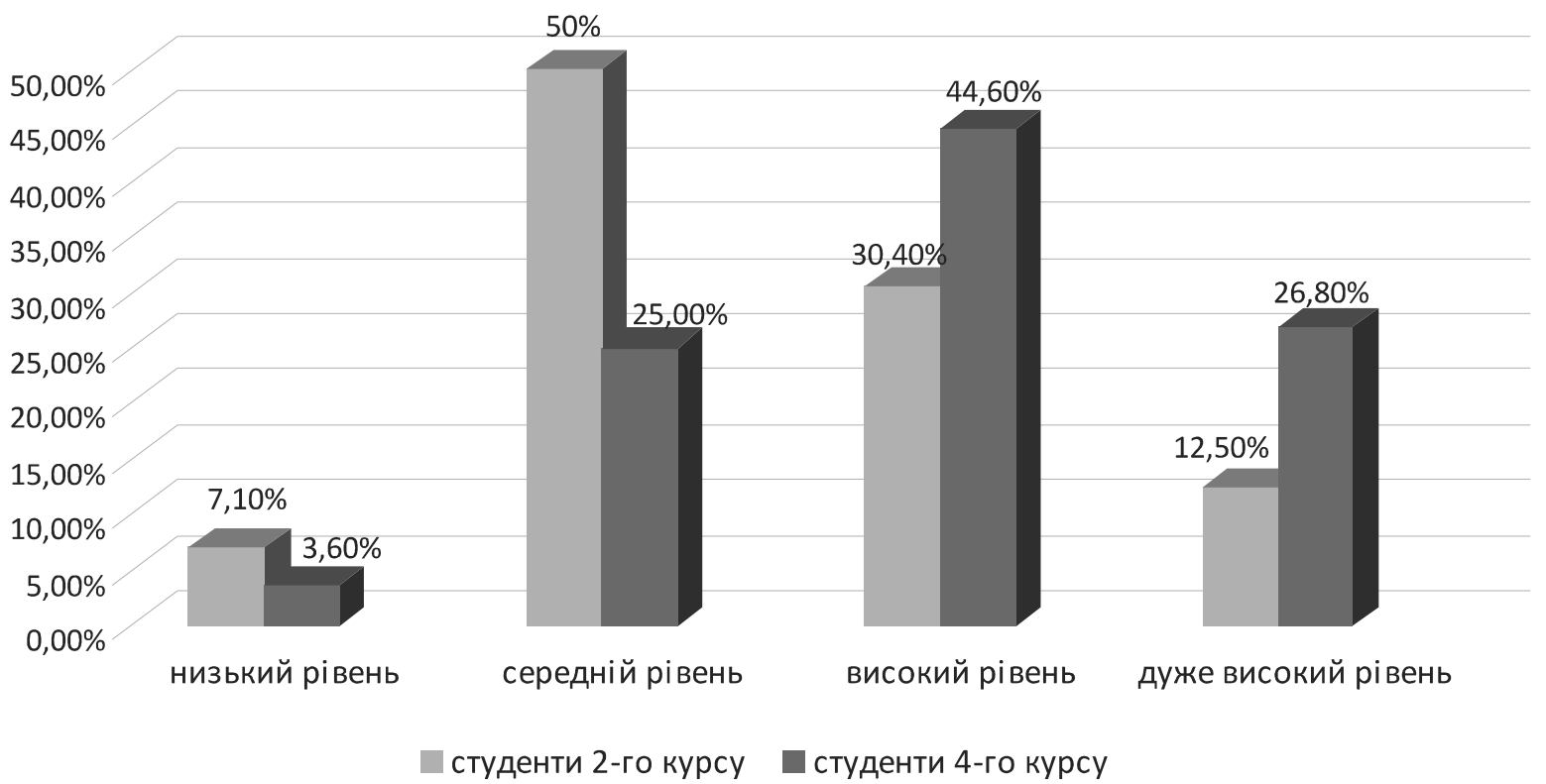

Рис. 1. Результати дослідження рівня мотивації досягнення за опитувальником Т. Елерса.

Ми дослідили, що за показником рівня мотивації досягнення успіху в студентів 2-го та 4-го курсів існують відмінності.

У більшості респондентів спостерігаються середній та високий рівні мотивації досягнення успіху. Середній рівень мотивації досягнення виявлений у 50 \% студентів 2-го курсу та 25 \% студентів 4-го курсу. Високий рівень мотивації у студентів 2-го курсу склав 30,4 \% респондентів, у студентів 4-го курсу - 44,6 \%.

Цікавим є отриманий результат дослідження, який показує, що на 4-му курсі збільшилася кількість студентів із високим (44,6 \%) та дуже високим (26,8 \%) рівнями мотивації досягнення успіху порівняно зі студентами 2-го курсу, у яких показник високого рівня мотивації становить 30,4 \%, а дуже високого - 12,5 \% (рис. 2).
Відповідно до отриманих даних, нами було виділено предиктори мотивації досягнення успіху, які ми поділили на 3 групи.

Перша група. Студенти з дуже високою та високою мотивацією досягнення. Їм властива активність, ініціативність, здатність долати перешкоди, наполегливість у досягненні поставлених цілей. Продуктивність навчальної діяльності у них не залежить від зовнішнього локусу контролю, а притаманне домінування внутрішніх мотивів.

Друга група. Студенти з середнім рівнем мотивації досягнення.

Для цієї групи характерними є менша ініціативність та наполегливість у досягненні мети, залежність від зовнішніх стимулів, менша орієнтація на успіх.

Третя група. Студенти з низьким рівнем мотивації. 


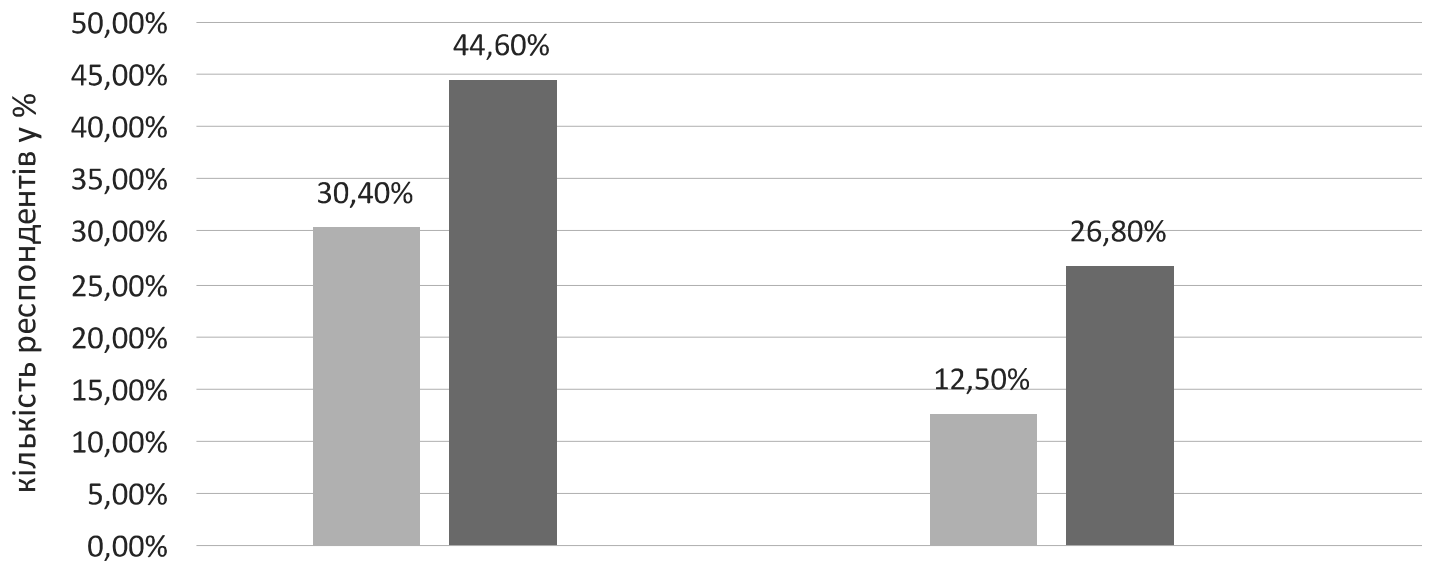

високий рівень мотивації

дуже високий рівень мотивації

студенти 2-го курсу ш студенти 4-го курсу

Рис. 2. Динаміка мотивації досягнення успіху.

Психологічні ознаки для цієї групи були наступні: невпевненість у собі, відчуття дискомфорту від подолання перешкод, домінування зовнішньої мотивації над внутрішньою, орієнтованість на уникнення помилки.

Узагальнені результати дослідження свідчать про те, що збільшення студентів з високою та дуже високою мотивацією досягнення на 4-му курсі відбувається тому, що зовнішні фактори втрачають свою значущість у мотиваційній структурі майбутніх лікарів і починають переважати внутрішні мотиви. Для розвитку мотивації досягнення для майбутніх лікарів створюється розвиваюче освітнє середовище з використанням інноваційних методів навчання, які сприяють усвідомленню студентами важливості знань і практичних навичок для успішного оволодіння ними майбутньою професійною діяльністю, розвитку клінічного мислення. Заслуговує на увагу застосування такого інноваційного методу, як симуляційне навчання, яке також є одним із факторів ефективної мотивації досягнення успіху студентів-медиків в оволодінні майбутнім фахом. Центр симуляційного навчання сприяє засвоєнню знань та відпрацюванню різних клінічних навичок майбутніх лікарів завдяки використанню манеке-

\section{Список літератури}

1. Психологія діяльності та навчальний менеджмент : навч. посіб. / [М. В. Артюшина, Л. М. Журавська, Л. А. Колесніченко та ін.] ; за заг. ред. М. В. Артюшиної. - K. : KHEУ, 2008. - 336 с.

2. Занюк С. С. Психологія мотивації / С. С. Занюк. К. : Либідь, 2002. - 304 с. нів-симуляторів, тренажерів і стандартизованих пацієнтів. Симуляційні методи навчання дозволяють майбутньому лікарю здобувати клінічний досвід без ризику для пацієнта, не обмежувати кількість повторів при відпрацюванні практичної навички, реалізувати професійні навички і вміння відповідно до встановленого щодо даних умов алгоритму.

Залученість студентів до активної науково-дослідної діяльності формує у них навички самостійної роботи та планування своєї діяльності, заохочує до самоосвіти як у професійному, так і в особистісному аспекті.

Висновки. Результати проведеного нами дослідження свідчать про виявлену динаміку мотивації досягнення успіху в студентів-медиків. На 4-му курсі кількість студентів-медиків із високим та дуже високим рівнями мотивації досягнення більша, ніж на 2-му курсі. Це говорить про те, що на здійснення ними навчальної діяльності впливає система внутрішніх мотивів, що забезпечує ефективне оволодіння майбутнім фахом.

Проведене дослідження не вичерпує всіх аспектів даної проблематики. Перспективою подальших досліджень буде вивчення зв'язку особистісних характеристик з мотивацією досягнення успіху.

3. Зеер Э. Ф. Психология профессий : учебное пособие для студентов вузов / Э. Ф. Зеер. - 3-е изд., перераб., доп. - М. : Академический Проспект; Фонд “Мир”, 2005. - 336 c.

4. Хекхаузен Х. Психология мотивации достижения / Х. Хекхаузен. - СПб. : Смысл, 2001. - 860 с. 
5. Сучасні можливості підвищення мотивації студентів до навчання / Л. В. Беш, Б. Я. Дмитришин, О. М. Беш [та ін.] // Львівський клінічний вісник. - 2017. - № 1 (17). C. 60-64. - Режим доступу : http://lkv.biz/wp-content/ uploads/2017/05/Besh-L.-et-al.2017.pdf.

6. Гилюн О. В. Освітні мотивації студентської молоді / О. В. Гилюн // Грані : наук.-теорет. і громад.-політ.

\section{References}

1. Artiushyna, M.V., Zhuravska, L.M., Kolesnichenko, L.A., Kotykova, O.M., \& Radchenko, M.I. (2008). Psykholohiia diialnosti ta navchalnyi menedzhment: navch. posib. [Psychology of activity and educational management: manual]. Artiushyna M.V. (Ed.). Kyiv: KNEU [in Ukrainian].

2. Zaniuk, S.S. (2002). Psykholohiia motyvatsii [Psychology of motivation]. Kyiv: Lybid [in Ukrainian].

3. Zeer, E.F. (2005). Psikhologiya professiy: uchebnoye posobiye dlya studentov vuzov 3-e izd., pererab., dop. [Psychology of professions: a textbook for university students. The 3rd ed. rew.]. Moscow: Akademicheskiy Prospekt; Fond "Mir" [in Russian].

4. Khekkhauzen, Kh. (2001). Psyihologiya motivatsii dostizheniya [Psychology of achievement motivation]. SaintPetersburg: Smysl [in Russian].

5. Besh, L.V., Dmytryshyn, B.Ya., Besh, O.M., Yaskevych, O.I., \& Matsiura, O.I. (2017). Suchasni mozhlyvosti альманах / Дніпропетр. нац. ун-т ім. О. Гончара ; Центр соц.-політ. досл. - 2012. - № 1. - С. 102-104.

7. Прядко Н. О. Мотивація досягнення як детермінанта успіху в професійній діяльності особистості / Н. О. Прядко // Вісник. - 2015. - № 127. - С. 177-180. Режим доступу : http://visnyk.chnpu.edu.ua/?wpfb_ $\mathrm{dl}=1574$.

pidvyshchennia motyvatsii studentiv do navchannia [Modern possibilities of increasing the motivation of students to study]. Lvivskyi klinichnyi visnyk - Lviv Clinical Herald, 1 (17), 60-64. Retrieved from: http://lkv.biz/ wp-content/uploads/2017/05/Besh-L.-et-al.2017.pdf [in Ukrainian].

6. Hyliun, O.V. (2012). Osvitni motyvatsii studentskoi molodi [Educational motivations of student youth]. Dnipropetrovsk: nats. un-t im. O. Honchara-O. Honchar Dnipropetrovsk National University, 1, 102-104 [in Ukrainian].

7. Priadko, N.O. (2015). Motyvatsiia dosiahnennia yak determinanta uspikhu $\mathrm{v}$ profesiinii diialnosti osobystosti [Motivation of achievement as a determinant of success in the professional activity of the individual]. Visnyk-Bulletin, 127, 177-180. Retrieved from: http://visnyk.chnpu.edu. ua/?wpfb_dl=1574 [in Ukrainian]. 